\title{
The effect of nutritional intake on outcome of pregnancy in smokers and non-smokers
}

\author{
BY F. M. HASTE', O. G. BROOKE ${ }^{2}$, H. R. ANDERSON ${ }^{1}$ AND J. M. BLAND $^{1}$ \\ Departments of ${ }^{1}$ Public Health Sciences, and ${ }^{2}$ Child Health, St George's Hospital Medical School, \\ Cranmer Terrace, London SW17 ORE
}

(Received 3 July 1990 - Accepted 24 September 1990)

\begin{abstract}
The relationship between nutrient intake and pregnancy outcome (adjusted birth weight and gestational age) was investigated in randomly selected non-smokers $(n$ 97) and in heavy smokers $(15+$ cigarettes/d) $(\boldsymbol{n} 72)$ booking for ante-natal care at a hospital in South London. Weighed dietary intakes ( 7 d) were obtained at 28 and 36 weeks gestation. Birth weight was adjusted for gestational age, maternal height, parity and sex of infant.

Compared with non-smokers, intakes of micronutrients and fibre were lower in smokers at both 28 and 36 weeks, and smokers reduced their intakes more in late pregnancy. The babies of smokers had a lower adjusted birth weight but there was no difference in length of gestation between smokers and nonsmokers. After controlling for smoking, social class and alcohol consumption, nutrient intakes at 28 weeks were found to have no effect on adjusted birth weight. However, intakes of protein, zinc, riboflavin and thiamin at 36 weeks, and the change in intakes of these nutrients (plus iron) between 28 and 36 weeks, had independent positive effects on birth weight. Some of the effect of smoking on birth weight appeared to be mediated through differences in nutrient intakes. Smoking explained $14.3 \%$ of the variance in birth weight in this population and a further $2 \cdot 4-7 \cdot 2 \%$ was explained by change in nutrient intakes between 28 and 36 weeks. It is recommended that women in pregnancy do not reduce their dietary intakes in late pregnancy.
\end{abstract}

Diet: Pregnancy : Smoking: Gestational age: Birth weight

There has been considerable interest over the past 25 years in the effects of nutrition in pregnancy on fetal growth. Results of supplementation studies in several Third World populations, and in poor communities in the USA (Ebbs et al. 1941; Lechtig et al. 1975b; Stein et al. 1978; Mora et al. 1979; Prentice et al. 1983; Whitehead et al. 1983) have been contradictory, largely because of different or inconsistent methodology and different initial planes of nutrition. The issue remains important, however, as poor women continue to produce small babies in all parts of the world, and to have a high perinatal mortality risk (Lechtig et al. 1975a; Rush \& Cassano, 1983).

Smoking is known to reduce birth weight (Meyer et al. 1976; Rantakallio, 1978) and to increase preterm delivery (Meyer, 1977). Findings from the St George's Birthweight Study (of which the present study is a part) have indicated that smoking in this population is the most important environmental influence on birth weight, and that social, economic and psychological factors have little independent effect. Alcohol was found to reduce birth weight only in smokers (Brooke et al. 1989; Peacock et al. 1990). Several studies have suggested that part of the effect of smoking on birth weight may be mediated by nutritional factors through reduced overall energy intake or weight gain, or both (Rush, 1974; Davies et al. 1976; Garn, 1979), but dietary information to date has been insufficient to test this hypothesis. We have reported that smokers had poorer quality of diet than non-smokers in pregnancy, although their energy intakes were not significantly reduced, and that this effect was independent of the effects of social class (Haste et al. 1990). Other studies, using 
less rigorous methods (e.g. $24 \mathrm{~h}$ recall methods of data collection) have been conflicting, reporting that intakes of smokers were higher (Haworth et al. 1980; Picone et al. 1982), lower (Papoz, 1982), or similar (Smithells et al. 1977, using weighed intakes) to those of non-smokers in pregnancy. Further impetus to the hypothesis that the effects of smoking may be mediated through nutritional factors has been provided by studies of biochemical nutritional status which have indicated that smokers have lower circulating levels of folate (Witter et al. 1982; Nakazawa et al. 1983), vitamin C (Calder et al. 1963; Pelletier, 1970, 1975; Schorah et al. 1978) and carotene (Witter et al. 1982), and by studies indicating that birth weight is associated with lower circulating zinc (Meadows et al. 1981; Patrick et al. 1982; Simmer \& Thompson, 1984; Wells et al. 1987), carotene and amino acids (Crosby et al. 1977).

In the present study we have investigated the effects of nutrient intakes in pregnancy on two measures of pregnancy outcome - birth weight adjusted for gestational age, and gestational age at delivery - in an unselected group of heavy smokers $(15+$ cigarettes $/ d)$ and a group of randomly selected non-smokers from the ante-natal clinics at St George's Hospital in London who competed a $7 \mathrm{~d}$ weighed dietary intake in mid- and late pregnancy.

\section{METHODS}

The study was carried out at St George's hospital, Tooting, London, as part of the larger St George's Birthweight Study (Brooke et al. 1989). All Caucasian women presenting at the ante-natal clinics from August 1982 to August 1984 were given a structured questionnaire by trained interviewers to obtain details of smoking habit. All women who reported smoking $15+$ cigarettes/d in the previous week were selected for the smoking group. Nonsmokers were selected using random number tables from women who reported that they had never smoked. Information on income, social class, marital status, education and housing tenure was obtained by the interviewers. Subjects were asked to do a $7 \mathrm{~d}$ weighed dietary intake at 28 weeks and at 36 weeks gestation. Details of the methods of weighed dietary intake have been reported elsewhere (Haste et al. 1990). Data used in the analysis were mean daily intakes of $7 \mathrm{~d}$ recorded intakes. Data were analysed using $\mathrm{McC}$ Cance and Widdowson's The Composition of Foods (Paul \& Southgate, 1978). Nomenclature of nutrients is that used in McCance and Widdowson's The Composition of Foods. Of those asked to participate in the study 139 were smokers and 149 were non-smokers. Twenty-six non-smokers and thirty-nine smokers refused to take part, either initially or subsequently, twelve women aborted or moved away, and five records were considered incomplete or inadequate. Complete dietary data at 28 weeks were obtained for ninety-four smokers and 112 non-smokers. Two of the non-smokers had started smoking by 28 weeks and so were excluded from the analysis. All smokers were still smoking at 28 and 36 weeks. Of the participants seventy-two smokers and ninety-seven nun-smokers completed a further week's data collection at 36 weeks, and these subjects form the population for this analysis.

Obstetric data including maternal height and parity were obtained from the obstetric case notes. Gestational age at delivery was calculated from the agreed delivery data recorded by the attending obstetrician using last menstrual period and early ultrasound examination data. Birth weight was measured by the midwife within $30 \mathrm{~min}$ of delivery using a Marsden spring balance. Birth weight is known to vary with gestational age, maternal height, age and parity, and sex of the infant. In order that comparisons can be made between individuals in whom these characteristics differ, i.e. to allow for these confounding factors, we calculated an adjusted birth weight as follows: the expected birth weight-for-gestational age was calculated using a large data set from Sheffield ( $n 1500$, stratified by gestational age) as an external standard. Using the ratio of observed: expected 
values, birth weight was adjusted for gestational age. Further adjustments were made for maternal parity and height, and sex of infant, using linear regression equations from the St George's study population. No adjustment for maternal age was required. These techniques have been described in detail elsewhere (Brooke et al. 1989; Bland et al. 1990). Birth weight presented has been adjusted to a reference birth weight for a male infant of 40 weeks gestation of a mother of parity $1+$ and height $1.60 \mathrm{~m}$.

For the purpose of analysis, variables which did not have an approximately Normal distribution were logarithmically transformed. We have already reported that maternal height and social class have an effect on dietary intake, therefore in the analysis of the effect of smoking on dietary intake we used three-way analysis of variance (SPSS-X (1983), ANOVA procedure, regression method) to test the significance of the effect of smoking on dietary intake, while allowing for the effects of social class and maternal height simultaneously. Student's $t$ tests were used to test for the significance of the difference between group means of adjusted birth weight and gestational age. Multiple regression was used to test for the significance of the effects of various factors on birth weight, using a method in which the effect of each factor is calculated taking into account the effects of all other factors in the equation simultaneously. $R^{2}$ values from this analysis are presented, with their significance values where specified.

\section{RESULTS}

Non-smokers were taller than smokers $(163.7$ (SD 5.4) v. 160.6 (SD 6.0), $P<0.001)$ so the effect of maternal height was allowed for in the analysis where appropriate.

Nutrient intakes of smokers were lower than those of non-smokers at both 28 and 36 weeks after allowance had been made for the effects of maternal height and social class, particularly for micronutrients (minerals and vitamins) and fibre (Table 1). Energy intakes were not significantly lower. Both smokers and non-smokers significantly decreased their energy intakes from 28 to 36 weeks, and smokers also reduced their intakes of other macroand micronutrients.

Birth weight, presented as adjusted birth weight (birth weight adjusted for gestational age, maternal height and parity, and sex of infant) was significantly lower in smokers than non-smokers (Table 2). There was no difference in mean gestational age at delivery between smokers and non-smokers.

The effects of dietary intake on adjusted birth weight were assessed in a multipleregression analysis including smoking and alcohol consumption. We have previously reported that nutrient intake varies significantly with social class (Haste et al. 1990) thus, social class was also included in the present analysis. There was no significant independent effect of intake of any nutrient at 28 weeks on adjusted birth weight but intake of protein, zinc, thiamin and riboflavin at 36 weeks (model 1) had a positive independent effect on adjusted birth weight (Table 3). Also examined was the effect of change in nutrient intake between 28 and 36 weeks (model 2). Change in intakes of protein, minerals (iron and zinc) and vitamins (riboflavin, thiamin and vitamin $B_{6}$ ) also had a significant, positive effect on adjusted birth weight. There was no significant effect of change in energy intake.

Smoking explained $14.5 \%(P<0.0001)$ of the variance in adjusted birth weight, and the combined effects of smoking, alcohol and social class explained $18.9 \%$ before nutrient intakes were entered into the regression analysis. Addition of 36-week nutrient intakes (protein, $\mathrm{Zn}$, riboflavin and thiamin) separately to the regression models significantly increased the percentage of the variance explained $\left(R^{2}\right)$ by from $2.1 \%$ (protein; $(P<0.05)$ to $3.1 \%$ (riboflavin; $P<0 \cdot 05$ ), but decreased the $R^{2}$ of smoking by approximately equivalent amounts. Addition of change in nutrient intake the model increased the $R^{2}$ by 
Table 1. Nutrient intakes in smokers (S) and non-smokers (NS) at 28 and 36 weeks gestation

(Geometric mean values with their standard errors)

\begin{tabular}{|c|c|c|c|c|c|c|c|c|c|c|c|c|}
\hline \multirow[b]{3}{*}{ Nutrient } & \multicolumn{5}{|c|}{28 weeks } & \multicolumn{5}{|c|}{36 weeks } & \multirow{2}{*}{\multicolumn{2}{|c|}{$\begin{array}{c}\text { Statistical } \\
\text { significance } \\
\text { of difference } \\
28 \text { week } v \\
36 \text { week intake } \\
P<\end{array}$}} \\
\hline & \multicolumn{2}{|c|}{$\mathrm{S}$} & \multicolumn{2}{|c|}{ NS } & \multirow{2}{*}{$\begin{array}{c}\text { Statistical } \\
\text { significance of } \\
\text { - differencet: } \\
P<\end{array}$} & \multicolumn{2}{|c|}{$\mathrm{S}$} & \multicolumn{2}{|c|}{ NS } & \multirow{2}{*}{$\begin{array}{c}\text { Statistical } \\
\text { significance of } \\
\text { differencet: } \\
P<\end{array}$} & & \\
\hline & Mean & SE & Mean & SE & & Mean & $\mathrm{SE}$ & Mean & SE & & $\mathrm{S}$ & NS \\
\hline Energy $(\mathrm{MJ})^{*}$ & 8.0 & $0 \cdot 2$ & $8-4$ & $0 \cdot 2$ & 0.8 & $7 \cdot 4$ & $0 \cdot 3$ & $7 \cdot 8$ & $0 \cdot 3$ & $0 \cdot 8$ & 0.01 & 0.05 \\
\hline Protein (g) & 69 & 2 & 75 & 2 & 0.1 & 65 & 2 & 73 & 2 & 0.2 & $0-05$ & 0.07 \\
\hline Fat (g) & 88 & 3 & 91 & 2 & 0.9 & 81 & 3 & 88 & 3 & 0.9 & 0.05 & 0.08 \\
\hline Carbohydrate (g) & 230 & 8 & 238 & 6 & 0.8 & 217 & 8 & 230 & 7 & $0-9$ & 007 & 0.2 \\
\hline Fibre (g)* & 13.6 & 0.6 & $19 \cdot 5$ & 0.8 & 0.001 & $13 \cdot 2$ & 0.6 & $18 \cdot 3$ & $1 \cdot 0$ & 0.01 & $0-4$ & $0 \cdot 3$ \\
\hline Calcium (mg) & 910 & 34 & 1030 & 33 & 0.2 & 840 & 37 & 990 & 32 & $0 \cdot 2$ & 005 & 097 \\
\hline Iron $(\mathrm{mg})^{*}$ & $9 \cdot 3$ & 0.3 & 11.7 & 0.5 & 0.01 & $8 \cdot 5$ & 04 & $11 \cdot 2$ & 0.5 & 0.05 & 0.05 & 0.8 \\
\hline Zinc (mg)* & $8 \cdot 4$ & $0-3$ & $9 \cdot 7$ & 0.4 & 0.05 & $7 \cdot 7$ & $0 \cdot 3$ & $9 \cdot 5$ & 0.4 & 007 & 005 & 0.5 \\
\hline Carotene $(\mu \mathrm{g})^{*}$ & 826 & 80 & 1110 & 75 & 0.1 & 805 & 70 & 1100 & 75 & $0-1$ & 0.6 & 0.9 \\
\hline Thiamin (mg) & $1 \cdot 10$ & 0.04 & $1 \cdot 32$ & $0 \cdot 03$ & 0.01 & $1 \cdot 08$ & 005 & $1 \cdot 31$ & 0.04 & 0.05 & 0.6 & 07 \\
\hline Riboflavin (mg)* & $1 \cdot 7$ & 0.1 & 20 & 0.1 & 007 & 1.6 & $0 \cdot 1$ & $2 \cdot 1$ & $0 \cdot 1$ & 0.05 & 0.4 & 0.2 \\
\hline Vitamin $\mathrm{C}(\mathrm{mg})^{*}$ & 44 & 3 & 72 & 5 & 0.001 & 41 & 3 & 69 & 5 & 0.001 & $0 \cdot 3$ & 0.8 \\
\hline Vitamin $\mathrm{E}(\mathrm{mg})^{*}$ & $3 \cdot 6$ & 0.2 & $4 \cdot 8$ & $0 \cdot 2$ & 0.01 & $3 \cdot 4$ & 0.2 & $4 \cdot 5$ & $0 \cdot 2$ & $0 \cdot 06$ & 0.5 & $0 \cdot 1$ \\
\hline Vitamin $B_{6}(\mu \mathrm{g})^{*}$ & 1.03 & $0 \cdot 04$ & $1 \cdot 24$ & 0.04 & 0.01 & 098 & 0.05 & $1 \cdot 17$ & 0.05 & 0.08 & 0.2 & 0.2 \\
\hline Total folate $(\mu \mathrm{g})^{*}$ & 139 & 6 & 179 & 6 & 0.01 & 126 & 5 & 172 & 8 & 0.01 & 0.01 & 06 \\
\hline
\end{tabular}

* Logarithmically transformed for analysis.

+ Significance of the effect of smoking using 3-way analysis of variance allowing for the effects of maternal height and social class.

+ Paired $t$ test.

Table 2. Adjusted birth weight and gestational age at delivery from mothers who were smokers or non-smokers

(Mean values with their standard errors)

\begin{tabular}{|c|c|c|c|c|c|}
\hline & \multicolumn{2}{|c|}{$\begin{array}{l}\text { Smokers } \\
(n 72)\end{array}$} & \multicolumn{2}{|c|}{$\begin{array}{c}\text { Non-smokers } \\
(n 97)\end{array}$} & \multirow{2}{*}{$\begin{array}{c}\text { Statistical } \\
\text { significance } \\
\text { of } \\
\text { difference*: } \\
P<\end{array}$} \\
\hline & Mean & $\mathrm{SE}$ & Mean & $\mathrm{SE}$ & \\
\hline Adjusted birth wt $\uparrow(\mathrm{g})$ & 3384 & 49 & 3740 & 42 & 0.001 \\
\hline Gestational age (weeks) & $39 \cdot 9$ & $0 \cdot 2$ & 39.9 & $0 \cdot 1$ & 0.9 \\
\hline
\end{tabular}

* Student's $t$ test.

+ Adjusted for maternal height, parity, gestational age and sex of infant.

between $2.4 \%$ (Fe) and $7.2 \%$ (riboflavin) but the $R^{2}$ for smoking in these models generally did not decrease. Entering all these nutrients into the model increased the overall $R^{2}$ to $28.6 \%(P<0.01)$.

The regression coefficients for change in intakes of those nutrients that were found to have a significant effect on adjusted birth weight are given in Table 4, with the mean change in intakes of those nutrients for the population. This shows an estimated mean reduction of $82 \mathrm{~g}$ in adjusted birth weight for women who reduced their protein intakes, and of $87 \mathrm{~g}$ for women who reduced their riboflavin intakes. Similar differences were seen for other nutrients. 
Table 3. Percentage of the variance $\left(\mathrm{R}^{2}\right)$ in adjusted birth weight explained by smoking, nutrient intake at 36 weeks (model I), and change in nutrient intake in late pregnancy $($ model 2)*

\begin{tabular}{|c|c|c|c|c|c|c|c|c|}
\hline \multirow[b]{3}{*}{ Nutrient } & \multicolumn{4}{|c|}{ Model 1} & \multicolumn{4}{|c|}{ Model 2} \\
\hline & \multicolumn{3}{|r|}{ Nutrient } & \multirow[b]{2}{*}{$\begin{array}{c}\text { Total } \dagger \\
R^{2}\end{array}$} & \multirow[b]{2}{*}{$\begin{array}{c}\text { Smoking } \\
R^{2}\end{array}$} & \multicolumn{2}{|c|}{$\begin{array}{c}\text { Change in } \\
\text { nutrient }\end{array}$} & \multirow[b]{2}{*}{$\begin{array}{c}\text { Totalt } \\
R^{2}\end{array}$} \\
\hline & $\begin{array}{c}\text { Smoking } \\
R^{2}\end{array}$ & $R^{2}$ & $\begin{array}{c}\text { Statistical } \\
\text { significance: } \\
P<\end{array}$ & & & $R^{2}$ & $\begin{array}{c}\text { Statistical } \\
\text { significance: } \\
P<\end{array}$ & \\
\hline None entered $t$ & $14 \cdot 3$ & - & - & $18 \cdot 9$ & $14 \cdot 3$ & - & - & 18.9 \\
\hline Energy & $14 \cdot 0$ & $1 \cdot 0$ & $0 \cdot 2$ & $20 \cdot 0$ & $\mathrm{I} 4 \cdot 4$ & 0.6 & $0 \cdot 3$ & $19 \cdot 5$ \\
\hline Protein & $12 \cdot 8$ & $2 \cdot 1$ & 0.05 & $21 \cdot 5$ & $14 \cdot 5$ & $4 \cdot 1$ & 0.01 & $23 \cdot 5$ \\
\hline Fat & $14 \cdot 1$ & 0.5 & $0 \cdot 4$ & $19 \cdot 3$ & $14 \cdot 3$ & 0 & - & $19 \cdot 0$ \\
\hline Carbohydrate & $14 \cdot 5$ & $1 \cdot 2$ & $0 \cdot 2$ & $20 \cdot 0$ & $14 \cdot 3$ & 0 & 一 & $19 \cdot 1$ \\
\hline Fibre & $11 \cdot 7$ & $0 \cdot 9$ & $0 \cdot 2$ & $19 \cdot 8$ & $14 \cdot 3$ & 0.8 & $0 \cdot 3$ & $19 \cdot 6$ \\
\hline Calcium & $13 \cdot 5$ & 0.5 & $0 \cdot 4$ & $19 \cdot 3$ & $14 \cdot 3$ & $1 \cdot 2$ & 0.2 & $20 \cdot 0$ \\
\hline Iron & $11 \cdot 3$ & $1 \cdot 3$ & 0.1 & $20 \cdot 2$ & $12 \cdot 7$ & $2 \cdot 4$ & 0.05 & $21 \cdot 2$ \\
\hline Zinc & $11 \cdot 7$ & $2 \cdot 4$ & 0.05 & $21 \cdot 3$ & $13 \cdot 7$ & $6 \cdot 1$ & 0.001 & $25 \cdot 0$ \\
\hline Carotene & $12 \cdot 4$ & 1.9 & 0.06 & $20 \cdot 7$ & $14 \cdot 3$ & 0.6 & $0 \cdot 3$ & $19 \cdot 5$ \\
\hline Thiamin & $11 \cdot 8$ & $3 \cdot 2$ & 0.05 & $22 \cdot 0$ & $14 \cdot 3$ & $3 \cdot 0$ & $0 \cdot 05$ & $21 \cdot 8$ \\
\hline Riboflavin & $11 \cdot 2$ & $3 \cdot 1$ & 0.05 & $22 \cdot 0$ & $12 \cdot 5$ & $7 \cdot 2$ & 0.001 & $26 \cdot 2$ \\
\hline Vitamin $\mathrm{C}$ & $11 \cdot 0$ & 0.6 & $0 \cdot 3$ & $19 \cdot 5$ & $14 \cdot 4$ & 0 & - & $19 \cdot 1$ \\
\hline Vitamin $\mathrm{E}$ & $12 \cdot 7$ & 0.5 & $0 \cdot 4$ & $19 \cdot 3$ & $13 \cdot 8$ & $0-8$ & $0 \cdot 3$ & $19 \cdot 7$ \\
\hline Vitamin $\mathbf{B}_{6}$ & $12 \cdot 2$ & $1 \cdot 6$ & 0.08 & $20 \cdot 5$ & $14 \cdot 4$ & $3 \cdot 0$ & 0.05 & $21 \cdot 8$ \\
\hline Total folate & $11 \cdot 1$ & $1 \cdot 1$ & $0 \cdot 2$ & $20 \cdot 0$ & $14 \cdot 0$ & 0.8 & $0 \cdot 2$ & $19 \cdot 7$ \\
\hline Combined nutrients $\S$ & $10 \cdot 2$ & $3 \cdot 9$ & $0 \cdot 1$ & $22 \cdot 8$ & $12 \cdot 5$ & $9 \cdot 7$ & 0.01 & $28 \cdot 6$ \\
\hline
\end{tabular}

* Multiple regression analysis, with maternal social class and alcohol consumption also in each model

$\uparrow R^{2}$ for whole model.

\$ Model contains smoking, maternal social class and alcohol consumption.

$\S$ Protein, $\mathrm{Zn}$, thiamin, riboflavin, $\mathrm{Fe}$ and vitamin $\mathrm{B}_{6}$ entered simultaneously.

Table 4. The effect of change in intake of selected nutrients on mean adjusted birth weight $(\mathrm{g})$ of women who increased or decreased their intakes

\begin{tabular}{|c|c|c|c|c|c|c|}
\hline \multirow{2}{*}{$\begin{array}{l}\text { Change in } \\
\text { nutrient }\end{array}$} & \multirow{2}{*}{$\begin{array}{l}\text { Regression } \\
\text { coefficient* }\end{array}$} & \multirow{2}{*}{$\begin{array}{l}\text { Percentage } \\
\text { who } \\
\text { reduced } \\
\text { intake }\end{array}$} & \multicolumn{2}{|c|}{$\begin{array}{l}\text { Mean change in } \\
\text { nutrient intake }\end{array}$} & \multicolumn{2}{|c|}{$\begin{array}{c}\text { Estimated mean } \\
\text { change }(\mathrm{g}) \text { in } \\
\text { adjusted birth wt } \dagger\end{array}$} \\
\hline & & & Decrease & Increase $\ddagger$ & Decrease & Increase \\
\hline Protein (g) & 7 & 61 & $11 \cdot 7$ & $10 \cdot 2$ & 82 & 71 \\
\hline Iron (mg) & 24 & 56 & $2 \cdot 3$ & $2 \cdot 2$ & 55 & 53 \\
\hline Zinc (mg) & 49 & 54 & 1.9 & $1 \cdot 5$ & 93 & 73 \\
\hline Thiamin (mg) & 220 & $5 \mathrm{I}$ & $0 \cdot 3$ & 0.6 & 66 & 132 \\
\hline Riboflavin (mg) & 213 & 51 & 0.41 & 0.49 & 87 & 104 \\
\hline Vitamin $\mathrm{B}_{6}(\mu \mathrm{g})$ & 258 & 58 & $0 \cdot 23$ & $0 \cdot 20$ & 59 & 52 \\
\hline
\end{tabular}

* Regression coefficient for the effect of unit change in nutrient intake on adjusted birth weight (g) after allowing for the effects of smoking, social class and alcohol consumption.

$\dagger$ Estimated change in adjusted birth weight for mean changes in nutrient intake

+ Includes women who neither increased nor decreased their intakes. 
The change in dietary intakes of women who delivered small-for-gestational-age (SGA) babies (birth weight $<10$ th centile for gestational age) was compared with intakes of women who delivered appropriate-for-gestational-age (AGA) babies ( $>10$ th centile for gestational age). Of the mothers of SGA babies ( $n 21) 95 \%$ had reduced their protein intakes compared with $51 \%$ of the mothers of AGA babies $\left(\chi^{2} 10 \cdot 3, P<0.01\right)$. Change in intakes of other nutrients were not significantly different between these groups.

There was no effect of nutrient intakes at either 28 weeks or 36 weeks, nor of the change in intake, on gestational age at delivery.

\section{DISCUSSION}

Smokers had poorer dietary intakes in mid- and late pregnancy than non-smokers and they also reduced their intake of nutrients in late pregnancy more than did non-smokers. There was no evidence of an effect of dietary intake at 28 weeks on adjusted birth weight; however, there was evidence of an effect of dietary intake in late pregnancy. The lack of effect of nutrient intake at 28 weeks suggests that it is intake in later pregnancy that is more important to growth. This is not surprising since the greatest part of fetal growth occurs in the last 3 months of pregnancy. Populations which have been subjected to deprivation for part of pregnancy (e.g. war-time famine populations) have experienced the greatest effect on growth when the deprivation has been in the last trimester (Bergner \& Susser, 1970). A major feature of those periods of deprivation was severe restriction of energy, although one can reasonably assume that vitamins and minerals were also restricted. Supplementation studies which have enhanced protein intakes in an attempt to increase birth weight have had mixed success (Elwood et al. 1981; Campbell Brown, 1983). Many have resulted in poorer fetal outcomes, particularly those which gave high-protein supplements (Ebbs et al. 1941; Adams et al. 1978; Rush et al. 1980), so despite our finding of a positive relationship between fetal growth and protein intake we would not feel it wise to recommend increased intake. However, it does seem that reducing protein intake may have growth-retarding effects. The finding that $95 \%$ of the women who had growthretarded babies had reduced their protein intakes in late pregnancy strengthens this observation.

Smoking explained a higher percentage of the variance in adjusted birth weight than was found $(5 \%)$ in the larger, unselected population of the St George's Birthweight Study (Brooke et al. 1989). This is because the present sample was stratified by smoking habit with almost equal numbers of non-smokers as heavy smokers, therefore the effect of smoking would be greater than the effect in the larger study where $9 \%$ of the population were heavy smokers. The effect of nutrient intake, however, and particularly change in nutrient intake, was independent of the effects of smoking and there is no reason to suppose that an unselected sample which included moderate smokers would not show similar effects. Combined changes in nutrient intakes explained $9.7 \%$ of the variance in birth weight, an effect that was highly significant and almost comparable with that of smoking $\left(R^{2} 12.5 \%\right)$ in this regression model.

The findings suggest that some of the effect of smoking on birth weight may be mediated by lower nutrient intakes in late pregnancy since the proportion of the variance in adjusted birthweight that was explained by smoking was reduced by an amount equivalent to that attributable to intake of protein, $\mathrm{Zn}$, thiamin or riboflavin. However, a large effect of smoking remained, and the effects of changes in nutrient intake did not act as mediators of the smoking effect. Both smokers and non-smokers should be advised not to decrease their nutrient intakes in late pregnancy, and particularly not to reduce the quality of their diets in terms of vitamins, minerals and protein. 
The authors would like to thank Professors G. V. P. Chamberlain and R. Trussell and the staff of the ante-natal clinics, for facilitating the study, Mrs Alice Shaw and Ms Jane Griffin for their help in the collection of the dietary data, and Dr Janet Peacock for her statistical help and advice throughout the analysis.

Financial support was received from a Consortium of American Tobacco Companies, from South West Thames Locally Organised Research Committee and from the St George's Hospital Medical School Research Fund.

\section{REFERENCES}

Adams, S. O., Barr, C. D. \& Huenemann, R. L. (1978). Effect of nutritional supplementation in pregnancy. 1. Outcome of pregnancy. Journal of the American Dietetic Association 72, 144-147.

Bergner, L. \& Susser, M. W. (1970). Low birthweight and prenatal nutrition : an interpretative review. Pediatrics 46, $946-965$.

Bland, J. M., Peacock, J. L., Anderson, H. R. \& Brooke, O. G. (1990). The adjustment of birthweight for very early gestational ages: two related problems in statistical analysis. Applied Statistics 39, 229-239.

Brooke, O. G., Anderson, H. R., Bland, J. M., Peacock, J. L. \& Stewart, C. M. (1989). The effects on birthweight of smoking, alcohol, caffeine, socio-economic factors and psychosocial stress. British Medical Journal 298, $795-801$

Calder, J. H., Curtis, R. C. \& Fore, H. (1963). Comparison of vitamin C in plasma and leucocytes of smokers and non-smokers. Lancet i, 556.

Campbell Brown, M. (1983). Protein-energy supplements in primigravid women at risk of low birthweight. In Nutrition in Pregnancy, pp. 85-100 [D. M. Campbell and M. D. G. Gillmer, editors]. London: Royal College of Obstetricians and Gynaecologists.

Crosby, W. M., Metcoff, J., Costiloe, J. P., Mameesh, M., Stanstead, H. H., Jacob, R. A., McClain, P. E., Jacobson, S., Reid, W. \& Burns, G. (1977). Fetal malnutrition: an appraisal of correlated factors. American Journal of Obstetrics and Gynaecology 128, 22-31.

Davies, D. P., Gray, O. P., Ellwood, P. C. \& Abernethy, M. (1976). Cigarette smoking in pregnancy - associations with maternal weight gain and foetal growth. Lancet i, 385-387.

Ebbs, J. H., Tisdall, F. F. \& Scott, W. A. (1941). Influence of prenatal diet on mother and child. Journal of Nutrition 22, 515-526.

Elwood, P. C., Haley, T. J. L., Hughes, S. J., Sweetnem, P. M., Gray, O. P. \& Davies, D. P. (1981). Child growth and the effect of entitlement to a milk supplement. Archives of Diseases of Childhood 56, 831-835.

Garn, S. M. (1979). Is there nutritional mediation of the smoking effect on the fetus? American Journal of Clinical Nutrition 32, 1181-1184.

Haste, F. M., Brooke, O. G., Anderson, H. R., Bland, J. M., Shaw, A., Griffin, J. \& Peacock, J. L. (1990). Nutrient intakes during pregnancy: observations on the influence of smoking and social class. American Journal of Clinical Nutrition 51, 29-36.

Haworth, J. C., Ellestad-Sayed, J. J. M., King, J. \& Dilling, C. A. (1980). Fetal growth retardation in cigarettesmoking mothers is not due to decreased maternal food intake. American Journal of Obstetrics and Gynecology 137, 719-723.

Lechtig, A., Delgado, H., Lasky, R. E., Klein, R. E., Engle, P. L., Yarborough, C. \& Habicht, J. P. (1975a). Maternal nutrition and foetal growth in developing societies. American Journal of Diseases of the Child 129, 434-437.

Lechlig, A., Habicht, J. P. \& Delgado, H. (1975b). The effect of food supplementation during pregnancy on birthweight, Paediatrics 56, 508-519.

Meadows, N. J., Smith, M. F., Keeling, P. W. N., Ruse, W., Day, J. \& Scopes, J. W. (1981). Zine and small babies. Lancet ii, 1135-1137.

Meyer, M. B. (1977). Effects of maternal smoking and altitude on birthweight and gestation. In Epidemiology of Prematurity, pp. 81-103 [D. Reed and F. Stanley, editors]. Baltimore, MD: Urban \& Schwarzenberg.

Meyer, M. B., Jonas, B. S. \& Tonascia, J. A. (1976). Perinatal events associated with maternal smoking during pregnancy. American Journal of Epidemiology 103, 464-476.

Mora, J. D., Paredes, B., Wagner, M., Navarro, L., Suescun, J., Christiansen, N. \& Herrera, M. G. (1979). Nutritional supplementation and the outcome of pregnancy. American Journal of Clinical Nutrition, 32 , $455-462$.

Nakazawa, Y., Chiba, K., Nobuhiko, I., Kotoii, T., Sakamato, T. \& Ishizaki, T. (1983). Serum folic acid levels and antipyrine clearance rates in smokers and non-smokers. Drug and Alcohol Dependence 8, 201-207.

Papoz, L. (1982). Maternal smoking and birthweight in relation to dietary habits. American Journal of Obstetricss and Gynecology 142, 870 876.

Patrick, J., Dervish, G. \& Gillieson, M. (1982). Zine and small babies. Lancet i, 169-170.

Paul, A. A. \& Southgate, D. A. T. (1978). McCance and Widdowson's The Composition of Foods, 4th ed. London: H.M. Stationery Office. 
Peacock, J. L., Bland, J. M. \& Anderson, H. R. (1991). Effects on birthweight of alcohol and caffeine consumption in smoking women. Journal of Epidemiology and Community Health (In the Press).

Pelletier, O. (1970). Vitamin C status of cigarette smokers and non-smokers. American Journal of Clinical Nutrition 23, 520-524.

Pelletier, O. (1975). Vitamin C and cigarette smokers. Annals of the New York Academy of Sciences 258, $156-158$.

Picone, T., Allan, L. H., Schramm, M. H. \& Olsen, D. (1982). Pregnancy outcome in North American women. 1. Effects of diet, cigarette smoking and psychological stress on maternal weight gain. American Journal of Clinical Nutrition 36, 1205-1213.

Prentice, A. M., Whitehead, R. G., Watkinson, M., Lamb, W. H. \& Cole, T. J. (1983). Prenatal dietary supplementation of African women and birthweight. Lancet $\mathbf{i}, 489-492$.

Rantakallio, P. (1978). The effect of maternal smoking on birthweight and subsequent health of the child. Early Human Development 2, 371-382.

Rush, D. (1974). Examination of the relationship between birthweight, cigarette smoking during pregnancy and maternal weight gain. Journal of Obstetrics and Gynaecology of the British Commonwealth 81, 746-752.

Rush, D. \& Cassano, P. (1983). Relationship of cigarette-smoking and social class to birthweight and perinatal mortality among all births in Britain, 5 11 April 1970. Journal of Epidemiology and Community Health 37, 249-255.

Rush, D., Stein, Z. \& Susser M. (1980). A randomised controlled trial of prenatal nutritional supplementation in New York City. Pediatrics 65, 683-697.

Schorah, C. J., Zemrock, P. J., Sheppard, S. \& Smithells, R. W. (1978). Leucocyte ascorbic acid and pregnancy. British Medical Journal 39, 139-149.

Simmer, K. \& Thompson, R. P. H. (1984). Maternal zinc and intrauterine growth retardation. Clinical Science 68 , 395-399.

Smithelis, R. W., Ankers, C., Carver, M., Lennon, D., Schorah, C. J. \& Sheppard, S. (1977). Maternal nutrition in early pregnancy. British Journal of Nutrition 38, 497-506.

SPSS-X (1983). Statistical Package for the Social Sciences: User's Guide. Chicago: SPSS Inc.

Stein, Z., Susser, M. \& Rush, D. (1978). Prenatal nutrition and birthweight; experiments and quasi-experiments in the past decade. Journal of Reproductive Medicine 21, 287-297.

Wells, J. L., James, D. K., Luxton, R. \& Pennock, C. A. (1987). Maternal leucocyte zinc deficiency at the start of the third trimester as a predictor of foetal growth retardation. British Medical Journal 294, 1054-1056.

Whitehead, R. G., Prentice, A. M., Lamb, W. \& Paul, A. A. (1983). Maternal dietary supplementation during lactation and pregnancy in a rural African village in The Gambia. In Nutrition in Pregnancy, pp. 133-141 [D. M. Campbell and M. D. G. Gillmer, editors]. London: Royal College of Obstetricians and Gynaecologists.

Witter, F. R., Blake, D. A., Baumgardner, R., Mellitts, E. P. \& Neibyl, J. R. (1982). Folate, carotene and smoking. American Journal of Obstetrics and Gynecology 144, 857. 